\title{
Governments make inroads into medical self-regulation
}

Previously published at www.cmaj.ca

$\mathrm{O}$ ntario is planning to follow Alberta's lead and give itself the power to appoint a supervisor who could assume the regulatory duties of health profession regulating bodies such as the College of Physicians and Surgeons of Ontario (CPSO).

Similar legislation, passed two years ago in Alberta, has meant a "sword of Damocles" hangs over the College of Physicians and Surgeons of Alberta, says its registrar, Dr. Trevor Theman.

In that province, the move came in the wake of publicity about improper sterilization of equipment in a private doctor's office.

Dave Hancock, then Alberta's minister of health and wellness, said the authority to appoint an administrator to carry out the "power and duties of the college" was necessary because "there's a public confidence issue that needs to be addressed."

But the controversial provision in Ontario's Bill 179, which has already passed second reading, was not anticipated and was introduced without consulting the CPSO, says the college's registrar, Dr. Rocco Gerace.

The bill, to amend the Regulated Health Professions Act, states that a supervisor could be granted "the exclusive right to exercise all the powers of a Council and every person employed, retained or appointed for the purposes of the administration of this Act."

Gerace says the province has offered no explanation for granting itself this new power and emphasized that the concern is that it "could be implemented in the context of a politicized environment."

The Health Professions Regulatory Advisory Council advises the Ontario minister of health and long-term care and made many of the recommendations for change that are spelled out in Bill 179.

Neala Barton, spokeswoman for Health Minister Deb Matthews, said the provision in Bill 179 allowing for a supervisor to take over the operations of a college is an "accountability mechanism" prompted by concern about patient safety. "It is not something we see being used often, and only as a last

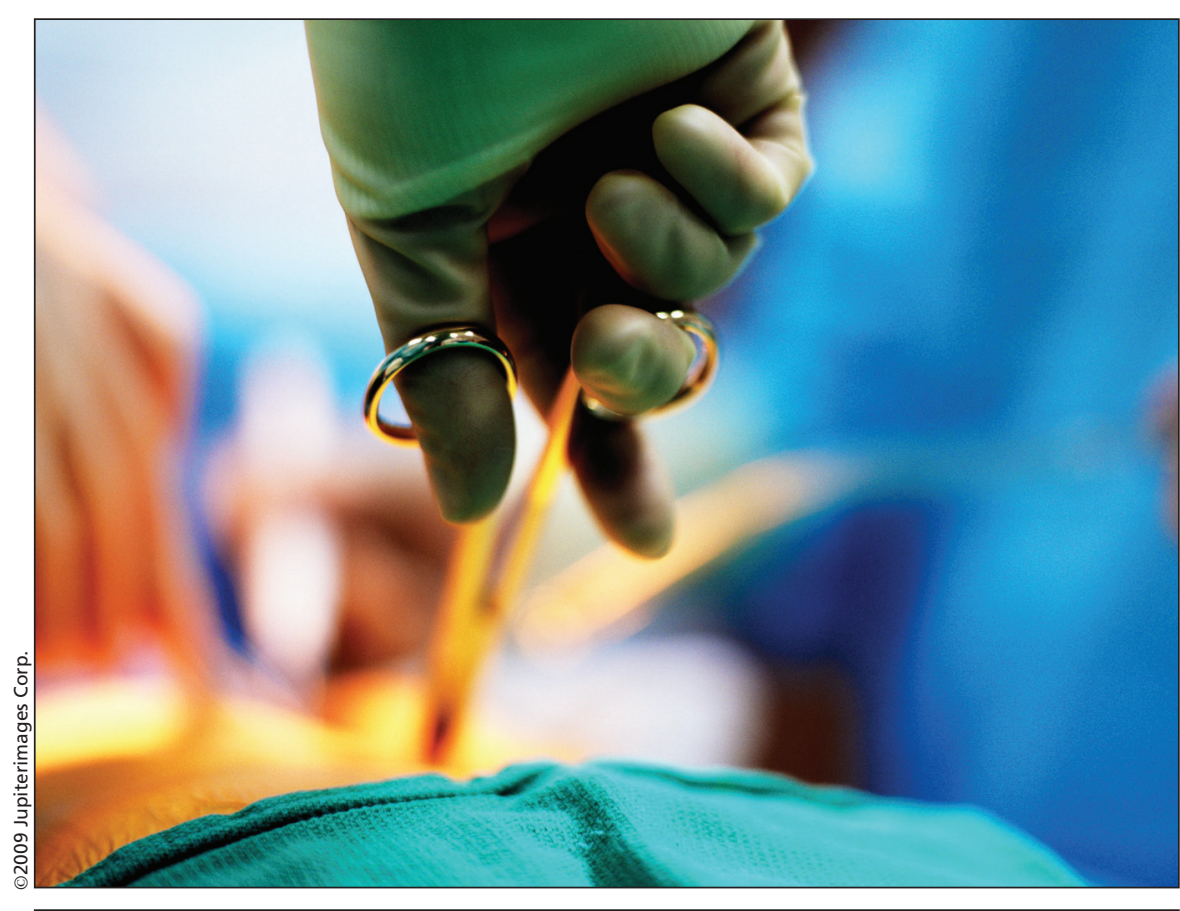

Alberta passed legislation granting the province power to assume the regulatory duties of the College of Physicians and Surgeons of Alberta in the wake of controversy about improper sterilization of medical equipment.

resort if patient safety is compromised."

There's a "general movement" toward more government involvement with regulated health professions, despite ample evidence of the benefits of self-regulation, says Marjorie Hickey, a Nova Scotia lawyer who specializes in the area.

She says the two provincial initiatives are a "much more direct step" into the regulation of professions, but other inroads include fair registration practices acts in Manitoba and Ontario, which created government bodies to oversee registration of professionals, and the amendment to the agreement on internal trade that deals with interprovincial mobility of professionals (CMAJ 2009. DOI:10.1503/cmaj.109-3050).

Provincial governments have not attempted similar inroads into the autonomy of other self-regulating professions, such as law, but the fact that many health professions receive government funding "may make it easier to impose oversight bodies," Hickey says.

As well, both Ontario and Alberta have umbrella health legislation, covering more than 20 regulated health professions, and this may have made it easier to pass Ontario's Bill 179 and Alberta's Bill 41, she says. In contrast, provinces such as Nova Scotia have separate legislation governing each regulated health profession, making the legislative change process more cumbersome.

In June, British Columbia repealed its Medical Practitioners Act and created umbrella legislation under which the health minister can "inquire" into "any aspect of the administration or operation of the college" if he considers it necessary in the public interest.

This government power seems "milder" than the existing Alberta legislation and proposed Ontario legislation, notes Susan Prins, communications director for CPSO.

Medical self-regulation has come under fire in other countries. For example, the General Medical Council in the United Kingdom, has undergone substantial change following public inquiries into medical scandals, including the notorious case of the physician serial killer Dr. Harold Shipman, who was found guilty of 15 murders and linked to more than 200 (CMAJ 2007. DOI:10.1503/cmaj.07-0431). 
General Medical Council governing council members are now appointed, as opposed to elected by the profession, while the criminal standard of proof for cases brought against doctors has been replaced by the civil standard, which makes it easier to convict, Professor Rudolf Klein, author of The New Politics of the NHS, stated in an email. As well, the governing council has embarked on a program of revalidating physician credentials.

In the United States, medical practice boards, which deal with issues of licensure, registration and discipline, are part of the executive branch of state governments, says Lisa Robin, senior vice president of member services with the Federation of State Medical Boards. Board members, including physicians, are appointed by the governor of the state.

Gerace says Ontario already has all the power it needs to oversee health regulators: "When concerns have been raised, we have engaged and worked collaboratively with government."
The Federation of Health Regulatory Colleges of Ontario, which represents 22 health regulatory colleges including the CPSO, also questions the need for the new powers. In its submission to the legislative committee reviewing Bill 179, the federation argues that Section 5 of the Regulated Health Professions Act already gives the minister "sweeping powers including the right to require a Council of a College to do anything that, in the opinion of the Minister, is necessary or advisable to carry out the intent of the legislation."

Federation President Anne Coghlan added that the model being proposed is "a poor fit" for regulatory colleges, since it is the same as one now applied to publicly-funded hospitals and school boards. "It has not procedural safeguards, no requirement to use Section 5, no maximum term, no appeal or review and no protection to prevent confidential or privileged information" being disclosed, she says. — Ann Silversides, CMAJ

DOI:10.1503/cmaj.109-3081

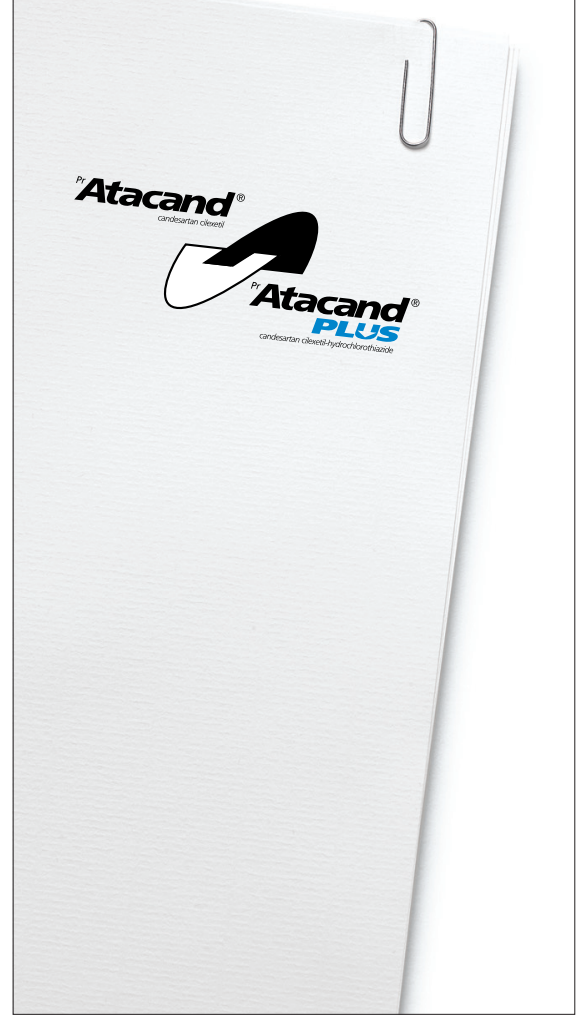

\section{More news at www.cmaj.ca}

C MAJ health news is now online daily as part of the journal's move to electronic publishing. The shift allows us to provide more stories to readers, on a more timely basis, while also publishing more Dispatches from the Medical Front. The following represents some of the pieces that have been posted at www.cmaj.ca since the last print edition of the journal.

Stem cell promises: Claims that stem cell research is a driver of economic growth could backfire, a law expert says. - Ann Silversides, CMAJ

Legal challenges: An analysis of health care-related legal challenges based on the Canadian Charter of Rights and Freedoms indicates that even failed bids can yield beneficial outcomes, while successful bids have not always been enforced. - Ann Silversides, CMAJ

New hurdle: A controversial clinical trial of two expensive treatments for Fabry disease is facing yet another hurdle, this time because of the worldwide shortage of one of the enzyme replacement therapies. - Ann Silversides, CMAJ

Delivering health services to Aboriginals: Federal reluctance to invest in local nursing stations and other forms of delivering primary health care within First Nations communities impairs health outcomes and inflates costs to provincial health budgets, health scientists say. Paul Webster, Toronto, Ont.

Dentist shortage: The United States may face a shortage of dentists commencing in 2014 as students migrate to specialties, schools close and older dentists retire. - Roger Collier, CMAJ

Pharma rep appointed to CIHR: The appointment of a senior executive from pharmaceutical giant Pfizer Canada to the governing council of the Canadian Institutes of Health Research has raised concern among some physicians about industry influence at the granting council. - Ann Silversides, CMAJ

Appeal lost: The Dalhousie University undergraduate medical program has failed to avert accreditation probation. donalee Moulton, Halifax, NS

\section{Dispatch}

Rwandan journey: A medical student muses about the value of working abroad during the summer.- Michael Slatnik, London, Ont.

DOI:10.1503/cmaj.109-3082 